\title{
A BIZALOM SZEREPE A TUDÁSTRANSZFER FOLYAMATÁBAN
}

A tanulmány témája a bizalom és a tudástranszfer kapcsolata. Megközelítési módjai közül izgalmasnak ígérkezik annak vizsgálata, hogyan válik a bizalom gazdasági hatótényezővé a tudástranszfer folyamatán keresztül. További lehetőség e reláció megfordítása, miszerint módosítja-e a gazdaság az egyén bizalomigényét, és ha igen, hogyan jelenik meg ez az egyén tanulással való kapcsolatrendszerében. A fenti területek részletesebb megismeréséhez kíván hozzájárulni e tanulmány, melynek fókuszában elsősorban azon tényezők részletes feltérképezése áll, amelyek leginkább befolyásolják a bizalom alakulásán keresztül a tudás megosztását. E témakörhöz kapcsolódóan választ keres a szerző arra a kérdésre is, hogy: hogyan merül fel a bizalmatlanság problémaköre, és miért élnek vissza a felek esetenként a partnerek információhiányával?

Az információgazdaság térnyerése nemcsak a gazdaság múködési módjait változtatja meg, hanem átértékelődnek az azt működtető emberi viszonyok és intézmények, így az emberek együttműködését irányító szabályok is (Hámori, 2003). Az önérdek mellett számos más tényező játszik szerepet az egyén magatartásában, amelyet különféle motivációk, attitűdök, érzelmek, magatartási szabályok és normák befolyásolhatnak (McCormick, 1997). Ilyen érzelmi attitűdnek tekinthető a bizalom, melyen keresztül az egyén saját személyes akarata, céljai, érzelmei gazdasági hatótényezőként jelennek meg.

A technikai változások és hálózatok hatására öszszetett alkalmazkodási folyamatok indultak meg a társadalmi-makrogazdasági szinttől kezdve a szervezeteken és intézményeken át egészen az egyénekig (Bőgel, 2004). A tudástranszfer ${ }^{1}$ jellemző megvalósulási formája a másoktól való tanulás, amelyet nem csupán önérdekkövető egyének cselekvéseként értelmezhetünk. A tudásintenzív ágazatok térnyerése nyomán megerősödött az információ és a vele való bánni tudás iránti igény. (Florida, R., 2004). A bizalom egyrészt információs állományunk jelentős részét teszi ki, másrészt az információ helyettesítőjeként is felfogható (Perelman, 1998). Kiemelt szerepet játszik a tudás megosztására irányuló tranzakciós folyamatokban, ahol ugyanúgy számolni kell a kockázattal, a tökéletlen informáltságból eredő bizonytalansággal és egymásra utaltsággal, mint a gazdasági szereplők más piaci tranzakcióinál2 (McKnight - Chervany, 2001). A bizalom fogalma közel áll az információéhoz, Arrow definíciója szerint az információ a bizonytalanság csökkentése (Arrow, 1973). Ugyanez elmondható a bizalomról is, azaz a bizalom csökkenti a bizonytalanságot (Perelman, 1998).

\section{Alkalmazott kutatási módszerek}

A bizalom kérdéskörének kvantitatív és kvalitatív eszközökkel való közös vizsgálatára egy OTKAkutatás ${ }^{3}$ keretein belül került sor. A vizsgálatba bevont szervezetek kiválasztásának szempontjai voltak: Informatikai alaptevékenység - Hazai alapítású szervezet Hazai piacvezető szerep és nemzetközi szinten való ismertség (kapcsolatok, partnerek, külföldi piac) Középvállalati nagyság (51-300 fő). Kvantitatív mintavételi módszerként az önkitöltős egyéni kérdőívet és szervezeti kérdőívet választottuk. A kapott adatokat ${ }^{4}$ leíró statisztikai módszerekkel (relatív ún. százalékos gyakorisági eloszlások) és esetenként matematikai statisztikai módszerekkel (korrelációszámítás) elemeztünk. ${ }^{5} \mathrm{Az}$ alkalmazott kvalitatív módszer az összetett 
kérdéstechnikával ${ }^{6}$ végzett mélyinterjú volt, amelynek segítségével az egyéni magatartás motivációit kívántuk megérteni, elemezni, tendenciákra, feltárt viselkedési jellemzőkre rámutatni. Az interjúszemélyek ${ }^{7}$ a kérdőívet kitöltők köréből kerültek ki, akik a szervezet fő alaptevékenységére jellemző munkaköröket (rendszermérnök, szakértő, szoftverfejlesztő programozó, IT-tanácsadó) képviselték.

A bizalom és tudástranszfer kapcsolata számos jelenséggel kapcsolatba hozható. Számos más jelenség kapcsolódik még témánkhoz, mint a bizalom és bizalmatlanság megszaladási jelenségként ${ }^{8}$ való értelmezése, a különböző védekező mechanizmusok ${ }^{9}$ és tabuk ${ }^{10}$ szerepe a tudástranszfer folyamatban. Ezek vizsgálata e tanulmány jövőbeni folytatása lehet.

Jelenlegi kiindulópontunk szerint bármely tudástranszfer elsődleges előfeltétele a tudás (mint tárgy), a bizalom (mint, szubjektív tényező) és kommunikáció (mint, közvetítő közeg) hármas egysége. Mindegyik tényező hordozója (egyben birtokosa) lehet valamely szerveződés (hálózat, szervezet) csoport vagy maga az egyén. A bizalomorientált megközelítést alapul véve a tanulmány terjedelmi korlátai miatt - három összefüggést tekintünk át közelebbről:

1. Bizalom, mint áru a tudás(transzfer) tranzakciójában.

2. Bizalom vs. bizalmatlanság a tudás kommunikálásában.

3. Tanulástámogatási formák és a bizalom.

\section{Bizalom, mint áru a tudás(transzfer)} tranzakciójában

A tudás folyamatos mozgásban van a gazdasági környezetben, létrehozzák, keresik, alkalmazzák, megosztják egymás között vagy visszatartására törekszenek. A tudásnak valódi piaca ${ }^{11}$ van, mert a tranzakciókat nem lehet csak formális eszközök útján érvényesíteni. Müködésének alapja a bizalom. ${ }^{12} \mathrm{~A}$ bizalom az elvárások összegző, értékelő dimenziója. Több megközelítésmódja ismert, leírják egyéni elvárásként, interperszonális kapcsolatként, tranzakciôs költséget befolyásoló tényezőként és társas struktúrák által alkotott jelenségként. Williamson-i értelemben azt az elvárást jelenti, hogy a másik személy (csoport, szervezet) explicit és implicit kötelezettségeinek megfelelően fog viselkedni, becsületes lesz és nem fogja az együttmúködési feltételeket egyoldalúan megváltoztatni (Williamson, 1998).

A hagyományos piaci környezetben számos kockázatforrás teszi bizonytalanná a tudásra vonatkozó tranz- akciókat, amelyek arányát tovább növeli az elektronikus piacok ${ }^{13}$ térnyerése és az IT-eszközök beemelésével járó speciális biztonságtechnikai problémák ${ }^{14}$ (Hámori, 2004).

A tudás tranzakciójának térbeli és időbeli keretei kitágulnak. Megvalósulhat a partnerek közvetlen fizikai értelemben vett személyes jelenlétével vagy közvetve a modern információs technológiák ${ }^{15}$ közvetítésével. A tranzakció történhet valósidejü tudásmegosztásként ${ }^{16}$ (a tudás átadása és fogadása egyidőben) és jelentős időbeli eltéréssel. Esetenként a tudást átadó személy gyakorlatilag eltűnik, ilyenek a hagyományosan nyomtatott és vállalati adatbázisokban, továbbá interneten elérhető tudáshordozók, mint például publikációk, technológiai leírások, projekteredmények, előírások, szabályok, továbbá más tudástartalmak (Kocsis, 2004). A valósidejü tudástranszfer folyamatában a tudás hordozója és átvevője személyesen vagy közvetve ismerik egymást, ez utóbbi esetben valamilyen közös pont (érdeklődés, munka, kapcsolatrendszer, érdek) hozza össze őket. A tranzakcióra vonatkozó szerződések nehezen szabályozhatók. A tudásmegosztás koordinálásában jelentős igény mutatkozik a tudást átvenni szándékozók részéről egyrészt a piaci koordinációra, azaz a szerződéses úton való szabályozásra (külső együttműködő partnerek ${ }^{17}$ esetén), másrészt a bürokratikus koordinációs eszközök alkalmazására (szervezeten belüli vezetôi előírások ${ }^{18}$ ). A bizalom természete miatt elsősorban a tudáshordozók reciprok altruizmusán alapuló tudástranszfer tűnik a leghatékonyabbnak a nem vagy nehezen kodifikálható tudás átadásánál. A reciprok altruizmus ${ }^{19}$ az altruizmus legelterjedtebb változata, egyfajta szívesség vagy segítség, amely a hasonló mentalitás elvárásán alapul.

A bizalom nemcsak a tudás tranzakciójának elengedhetetlen feltétele, hanem a tudás átadásának hatékonyságát meghatározó tényezője is. Makrobizalomnak (confidence) tekinthető a technikai rendszer infrastruktúrája, IT-technológia, adatbázisok, hálózatok és müködésükbe vetett bizalom, valamint az ezeket szabályozó jogintézmények. ${ }^{20}$ Mikrobizalmi szintet (trust) feltételez a közvetlen formális vagy informális kapcsolatban lévők tudásmegosztása, az egymástól való tanulás (Hámori, 2004).

Van egy tucat ember, akivel jól megértjük egymást, és ez nem egy formalizált valami, hanem egyszerüen jól tudunk együtt dolgozni, legyen az egy üzletágban szakértő, kereskedő, egy tulajdonos vagy egy másik igazgató, van egy ilyen csoport, akivel kölcsönösen jó affinitás van. 
A tudástranszfer aktorai közötti kapcsolat lehet szimmetrikus partneri viszony, ahol a tudásmegosztást kölcsönösen elvárhatják a felek vagy alapulhat aszimmetrikus kapcsolaton, ahol egyirányú tudásmegosztásra kerül sor. Ez utóbbi aszimmetria származhat az aktoroknak a tudástranszfer folyamatban betöltött szerepéből - mentori ${ }^{21}$ viszony vagy gyakornoki ${ }^{22}$ kapcsolat ${ }^{23}$ - továbbá az aktorok közötti súrlódásokból. ${ }^{24} \mathrm{~A}$ tudástranszfer általános akadályozó tényezői között említhetjük a bizalom hiányát, a befogadók abszorpciós képességéne ${ }^{25}$ fogyatékosságait, a segítségkéréssel szembeni intoleranciát és a tudás kizárólagos birtokosainak ellenérdekeltségét ${ }^{26}$ a tudás megosztásában (Davenport - Prusak, 2001). Mások a tudást átvevő aktorok potyázó viselkedésére (free riding) helyezik a hangsúlyt (Putnam, 1994). Az egyén magatartása oldaláról jelentkező tényezőket a tudáshordozó és a tudást átvevő szempontjából is csoportosíthatjuk. A tudásgazda részéről az egyén hajlandósága és készsége a tudás megosztására, az átadni kívánt tudás kódolásának képessége befolyásolja leginkább a tudástranszfert. A tudás átvevőjének részéről az egyén képessége a kapott tudás dekódolására és megértésére, valamint az egyén hajlandósága és készsége a kapott tudás elfogadására határozza meg a tudásmegosztás hatékonyságát (Kocsis, 2004).

Az aszimmetriát tovább árnyalja, ha az aktorok eltérő gazdasági, kulturális és etikai háttérrel rendelkeznek, ebből eredően nem találják a megfelelő értelmezési keretet, mint közös nyelvet. A bizalmatlanság foka sokféle formában mérhető. Az üzleti tranzakcióknál való előrefizetést Magyarországon ${ }^{27}$ 10\% arányban követeli meg az eladó a vevőtől, míg a többi országban ${ }^{28}$ ez jóval nagyobb, $40 \%$ körüli. Ez a bizalom erősödését mutatja, minél megbízhatóbb mindkét fél, annál erősebb a bizalom, annál kisebb a tranzakciós költség. Kornai kiemelt szerepet tulajdonít az eltérő történelmi múltnak, amelyet ,path dependence 29 " fogalommal jelöl a szakirodalom (Kornai, 2004). A posztszocialista országokban, így Magyarországon is a bizalom és bizalmatlanság sajátos kombinációja ${ }^{30}$ alakult ki az emberekben, amely a piaci tranzakciók megváltozásával, generációs váltással (új gazdasági helyzetbe belenövő új fiatal nemzedék) és a bizalomteremtő új társadalmi jogintézmények kialakulásával, valamint elfogadásával (bizalom térnyerése, illetve. helyettesítésének elfogadott megjelenési formái) tűnik befolyásolhatónak.

Folyamatos versenyben vagyunk, erős minőségi kihívás van, azt gondolom, egyre inkább a minőséget választják itthon is az emberek ...
A minőségi szemléletet, a régi beidegződéseket mint a gyerekek és szülők között, hogy: ha valami gond van, jaj, csak ki ne derüljön - meg kell változtatnunk. Szerintem, ez a szemlélet alapvetően mindenkiben benne van, ezt a szemléletet próbáljuk levetkőzni, nehéz feltárni a problémáinkat, foglalkozni kell velük...

Nem kell félni az újtól, és nem félni attól, hogy belevágjunk más dolgokba, hogy felvegyünk olyan típusú munkatársakat, akikről nem is gondoltuk nyolc évvel ezelőtt, hogy alkalmazva lesznek a cégben...

Elég nagy kihívás, hogy az előírt szabályoknak minél inkább megfelelj a különböző pályázatoknál. A pályázatok mellett tudjál olyan állami, vállalati, egyéb megbízást is megszerezni, amivel a túlélésünket meg lehet oldani...

A tudás tranzakcióit a megosztott tudásért járó valószínűsíthető ellenszolgáltatással kapcsolatos bizonytalanság is akadályozza (Davenport - Prusak, 2001). Morális megzavarodottságot jelez, hogy a régi és új generációk mentalitásában együtt élnek a régi és új esetenként egymást kizáró - etikai normák. Amíg egy korábbi nemzetközi felmérés szerint Magyarországon az összeköttetésekben és a tisztességtelen magatartásban látták még a közelmúltban is a meggazdagodás és siker forrását (Örkény és mts., 2003), addig saját felmérésünk szerint a megkérdezett hazai célcsoport nagyobb szerepet tulajdonít a munka minőségének és a saját erőfeszítéseknek, azaz nagyobb a bizalom a piaci történések tisztességes eszközökkel való befolyásolhatósága iránt.

Csak úgy tudsz sikeres lenni, hogy ha tanulsz, egyrészt, ha a meglévő piaci folyamatokat jobban megismered, méghozzá megtervezett, strukturált formában... másrészt, ha nem ismered a körülményeket, a versenytársakat, a veszélyeket sem tudod feltérképezni és harmadrészt, ha nem tervszerủen próbálsz ismereteket szerezni a piacról, akkor elfolysz, egyszerủen nem tudsz akciókat hozzárendelni... Ahhoz, hogy te el tudd magad adni a munkaerő-piacon, ahhoz neked tanulni kell. Azért tanulsz, mert magadat naponta el kell tudni adni. Én nem ebben nőttem fel, nem is könynyü a 40 feletti korosztálynak ezt elhinni, sokkal nagyobb volt a munkahelyi biztonság, amit ma már el lehet felejteni, amit én ma nagyon nehezen tolerálok.

A tudás a bizonytalanság kezelésének fő eszköze. A bizonytalan társadalmi környezetet ellensúlyozni kívánó kölcsönös bizalom azonban akadályává is válhat a piaci folyamatoknak. Minél erősebb a bizalmi háló, annál nehezebb a piacra való belépés. A személyes reputációra - és nem a konkrét szerződésekre - épülő piaci döntések csökkentik a szerződésszegés bizonyta- 
lanságát, viszont szúkítik a lehetséges tranzakciók körét, azaz korlátozzák a versenyt. Átváltási (trade off) viszonylat van a bizalom és a verseny között. (Woodruff, 2003). Felmérésünk szerint a bizalom erősödése a vállalatok közötti együttműködésben elsősorban a makroszintű kapcsolatok szintjén következett be, így a piacra való belépés (és kilépés) rugalmasabb, alapvető szerepe van benne a tanulás és tudásmegosztás képességének. Ezt gyakran alárendelik az üzleti folyamatok költségkontrolljának, amely a makrobizalom iránti igény fokozottabb jelenlétét jelzi.

\begin{abstract}
Ma a cég alkalmazkodási képessége talán a legfontosabb, afelé, hogy meg tudjunk élni, afelé, hogy mit igényel a piac, afelé, hogy együtt tudjunk müködni a konkurenseinkkel, azon cégek felé, akiknek a képviseletét ellátjuk, eléggé sokváltozós környezetben vagyunk...

Kellene nálunk is, a saját területünkön belül, tovább képezni a srácokat, ezt saját magunk finanszíroztuk is, de szerintem ezt szervezett keretek között kellene végezni. Ez nincs definiálva a szervezetben. Ezt azért nem ismeri fel a cég, mert ez költség, nincs azonnal bevétel belőle, nálunk nagyon nagy a költségkontroll nyomás és ha ilyen nagy nyomás van, akkor nem ezek a dolgok élveznek prioritást házon belül..
\end{abstract}

A bizalom növelésének ${ }^{31}$ makroszintű kezelési lehetőségeiként három alapvető mechanizmust javasol Klang, ezek: a tranzakciók technikai biztonságának növelése, a korrektséget garantáló jogintézmények kiépítése és a társadalmi mechanizmusok kifejlesztése (Klang, 2001). Ezek biztosítása kettős, ún. paradox hatással járhat. Egyrészt hozzájárulhat a mikroszintű partnerek közötti személyes bizalom erősödéséhez, másrészt részben helyettesítheti azt. A felek közötti bizalom egyfajta helyettesítési kapcsolatban áll a bizalom intézményes garanciáival, de kisebb költséggel jár hozzájuk képest (Hámori - Szabó, 2004). Gazdasági előnyei közé tartozhat többek között: a tranzakciós költségek csökkentése; hatékonyabb, gördülékenyebb és gyorsabb megállapodások; írásbeliség mellőzése, partnercserék többletköltségeinek elmaradása, továbbá a szervezetek, csoportok, egyének alkalmazkodóképességének javítása. A tudásalapú tranzakciók makrobizalmi intézményeinek száma kevés. Ezek szabályozásában nagyobb szerepet töltenek be a környezeti elvárások és a vállalati kultúra részét képező magatartási normák, mint a konkrét jogi eszközök, szerződések. Egyre több azon vállalatok száma, amelyekben a mentori programokat - a formalizált tudásátadás részeként - az idősebb személyzet munkaköri leírásának explicit részévé teszik (Davenport - Prusak, 2001).
A tudástranszfer során megjelenő személyes bizalom megteremtése, növelése és megőrzése pénzügyileg nem mindig, vagy csak nehezen kifejezhető költségekkel jár. Ide tartozhatnak a reputáció kialakításának költségei, egy adott csoporthoz (gyakorlat- vagy tudásközösség) tartozás idő- és energia ráfordításai, az önként vállalt vagy szervezeti feladatként végzett mentori feladatok és más kapcsolódó tevékenységek.

Az MBA tanulásom az a saját befektetésem volt, ezzel együtt a saját kockázatvállalásom. Megtérült, sokkal jobban kerestem utána, mint MBA nélkül, tehát pénzben is megtérült, kapcsolatrendszerben is, amit bárhol, bármikor fel tudok használni és használok is. Életem legjobb befektetése volt..

Belső önképző kör (működik saját kezdeményezésből - kiegészítés szerzőtől), ahol... a terület egy képviselője csinál egy prezentációt, gyakorlati példát és akit érdekel, lemegy, beül..

Kevés fejlesztő gárda engedheti meg magának, hogy részt vegyen egy egész hetes tanfolyamon, mi most voltunk saját keretből... nem is annyira a pénz, hanem az időkiesés az, ami számít..

Van egy belső fórumunk a saját weboldalon és oda minden témában bárki, bármilyen témában írhat, és bárkinek üzenhet... Az ember az olyan, ha valamivel nagyon sokat foglalkozott, azt nehezen hagyja ott. Én, hogy most beleférceltem rengeteg energiát ebbe a területbe, akkor nehezen állok fel csak azért, mert valaki kétszer akkora pénzt kínál.

A tudástranszfer folyamatában ilyen bizalomépítő reputáció lehet a külső és belső szakmai-üzleti közvélemény, amelynek egyik felén maga a szervezet, másik felén annak tudáskezelése áll. Emellett jelentékeny bizalmat befolyásoló tényező a konkrét személyhez kötött tudástulajdonítás, illetve az ebből eredő reputáció, amely magában foglalja a tudáshordozó rangját és hírnevét. A reputáció valójában a bizalom kifejezésének mutatója, a szűkös vagy éppen túl sok információ kezelésében, minősítésében lehet szerepe, amelyet formálisan is nevesíthet a környezet.

Ide olyan embereket veszünk fel, akik jó eredménynyel végezték el az iskolákat, nagyon komoly felvételi szakmai feladatokat adunk azoknak, akiket ide felveszünk... Alapvetően más területen dolgoztam, és megkérdezte a cégvèzető, nem lenne-e kedvem egy másik üzletágat átvenni, izgalmas volt, ... valami más egy új dologba kezdeni, s azóta is visszahallottam, hogy én vagyok az egyike azoknak, akik üzletszerúen gondolkoznak... Voltam kórházigazgató, több cégnek az ügyvezetője, csődmenedzser, reorganizáltam nagy cégeket, egy olyan tapasztalatot gyüjtöttem össze, amivel más nem rendelkezhet... és ezt látják, és elis- 
merik... Ha kikérik a véleményemet, ha vannak témák, amikkel kapcsolatban megkeresnek. Ez sok esetben így van.

\section{Bizalom vs. bizalmatlanság a tudás kommunikációjában}

Minden tanulás előfeltétele a kommunikáció. Polányi a kommunikáció előfeltételeként értelmezi a bizalom és tekintély ${ }^{32}$ kialakulását. Bizalom hiányában lehetetlenné válna a kommunikáció, ezért a bizalom nem belőle fakad, hanem megelőzi azt (Polányi, 1994). A tudástranszfer két csatornán mehet végbe, egyrészt verbális (másképpen szándékolt, illetve direkt), másrészt nem verbális (másképpen nem szándékolt, illetve indirekt) úton. Az indirekt kommunikáció magasabb szinten egészíti ki a verbális kommunikációt olyan információkkal, ${ }^{33}$ amelyek a nyelvi szinten nem jelennek meg. A két csatorna együtt nyújt lehetôséget a tudás le nem írható összetevőinek leírására és megosztására és a tudástranszfer kontrollálására. Az aktorok hitelessége ${ }^{34}$ (kongruenciája) befolyásolja a felek bizalmi szintjének alakulását. A bizalmatlanság eredhet a nem megfelelően kommunikáló tudásgazda hiteltelennek tulajdonításából is.

A tudáshordozó iránti bizalom két eltérő dologra alapozódik: a tudáshordozó (közvetítő, tudásgazda) kompetenciájának és jó szándékának feltételezésére, továbbá a tudás átvevőbe vetett bizalomra. Az átvevő részéről bizalmat feltételező tudásgazda elvárja a tudást átvevő tanulási képességét, kapacitását és megfelelő attitüdjét is.

A tudástranszfer két részből áll, a tudástartalom továbbításából (kódolás a potenciális tudás átvevő felé) és annak befogadásából ${ }^{35}$ (dekódolás az átvevő(k) által). A tudás elérhetővé tétele önmagában még nem jelent tudásmegosztást. A hozzáférhetőséget biztosító szervezeti eszközök ${ }^{36}$ erősíthetik a befogadásra irányuló törekvéseket, de azt nem helyettesítik.

A belső adatbázisban vannak (ti. információk - kiegészítés a szerzőtől) a munkákról, megbeszélésekről memók, ezek használata több energiát és fáradtságot is igényel. Ezt józan belátásra szoktuk bízni... Van külön projektekre bontott könyvtár is, ahol megtalálhatók az anyagok. Az igazgatói tanács megbeszéléseirôl is készül ilyen írásos összefoglaló. Minden egyes heti gyűlés után a cégvezetô készít egy beszámolót, amit mindenki olvashat a belső hálózaton - a pénzügyi helyzetünktől kezdve bármilyen céges ügyig... Most van egy projekt-nyilvántartó rendszer és ez most gond, hogy írjuk, ne írjuk, miért felejtjük el.
A tudástranszfer folyamatát - a konstruktivistákhoz hasonlóan - az új tudás aktív, személyes megalkotásaként és társas tevékenységként értelmezzük. Tudásnak fogadjuk el a konkrétan kifejezhető tudástartamok mellett azokat a készségeket és képességeket is, amelyek a kommunikáció és az információfeldolgozás magasabb szintjét biztosíthatják az egyén számára (Ackermann, 1995). A svéd közgazdászok (Pelikan, Eliasson, Carlsson) szerint a tudás a kompetenciákban testesül meg. A kompetencia a svéd kompetenciaelméletben olyan szűkös gazdasági információ, amitől a többi szűkös információ transzferálhatósága függ, de amit magát nem lehet transzferálni. Az információ egyik fajtájának tekintik a kompetenciát, azaz az információk két szintjét különböztetik meg: (1) kommunikálható információ (adatok, döntési módszerek), (2) nem kommunikálható információ (kompetencia), amely ahhoz szükséges, hogy a kommunikálható információkat kezelni tudjuk (Carlsson - Eliasson, 1991).

A tudástranszfer szempontjából fontos alapkérdés egyrészt, hogy milyen tudás hogyan kodifikálható, azaz ragadható meg valamilyen leíró eszközzel, másrészt, hogy a tudás birtokosaként, hordozójaként az egyénen kívül csoportot vagy szervezetet is elfogadunk-e. A vállalat tudása komplex, dinamikus és sokoldalú, és az egyének tudásán alapul, így megértéséhez a tudás általános jellemzőiből lehet kiindulni. Lam felfogása szerint a tudás két dimenzió mentén elemezhető: (1) a tudás manifesztálódása és kifejezésmódja szerint explicit és implicit tudás, (2) ontológiai szempont szerint egyéni vagy kollektív (Lam, A., 1998). Az explicit tudás kodifikálható tudás, verbálisan kommunikálható, és így könnyen transzferálható. Az implicit tudás azt a tudást jelenti, amely intuitív, nem artikulálható, nem könnyen kodifikálható és transzferálható. Az implicit tudás transzferálása tehát szoros interakciót igényel az egyének között, valamint a kölcsönös megértésen és bizalmon alapul. Az explicit tudás logikai dedukció és formális tanulás (learning by studying) útján szerezhetô meg. Az implicit tudás a tapasztalaton és az egyéni akciókon alapszik, ezért csak tapasztalati tanulással (learning by doing) bővíthetô. (Hayek, 1948). Mivel az explicit tudás jól kodifikálható, ezért aggregálható is. Ezzel szemben az implicit tudás személyes, amely nehezen aggregálható, csak a tudás közvetlen használata révén lehet belőle hasznosítani. Az explicit és az implicit tudás kölcsönösen megalapozzák egymást. Az aktorok közötti tudástranszferek abban is különböznek egymástól, hogy hogyan tudják a tudás e két fajtája közötti interakciót közvetíteni. Azok a szervezetek, amelyekben az explicit tudás- 
transzfer a meghatározó, általában formális koordinációs és ellenőrzési struktúrával rendelkeznek. A személyes bizalom előfeltételeként és helyettesítőjeként vannak jelen a makrobizalmi mechanizmusok, mint a tranzakciók magas szintű információtechnológiai támogatása (adatbázisok, tudásmegosztás írott dokumentumai, biztonságos hozzáférhetőség) és a korrekt szervezeti szabály- és normarendszer. Az ilyen szervezetekben a feladatok nagymértékben standardizáltak, mert az explicit tudás könnyen kodifikálható és aggregálható. Ezzel szemben az implicit tudás inkább decentralizált struktúrát és informális koordinációs mechanizmust igényel, mert a tudás erősen kötődik az egyénekhez. Az implicit tudás szétszórtan, az egyes aktorokhoz kötődve van jelen, szubjektív, ezért nem standardizálható. Ebből következően az implicit tudástranszfer folyamata nagyfokú egyéni autonómiát és elkötelezettséget, valamint az ezekkel együtt járó magas szintű személyközi mikrobizalmi szintet feltételez saját munkatársai körében. A formális szakmai tudás szerepe kisebb, döntő az egyes tudásgazdák tapasztalata és a tudást átvenni szándékozóknak az új helyzetekhez való alkalmazkodása, valamint a tudástranszfert kiegészítő saját próbálkozások és tévedések (trial and error) szerepe.

Minél több személyes tudás interakciójára kerül sor, annál nagyobb az igény a szervezet más aktorai felé irányuló tudástranszferre és a kooperatív viselkedésre.

Olyan jellegü tudástranszferre, ami az üzletágak különböző megvalósításainak és felhalmozott tudásának mások számára történő átadására vonatkozik, nincs fórum. Én dolgoztam olyan helyen, ahol minden projektnél kötelező volt szóbeli tájékoztatón való kiértékelés, ahová a cég más projektekben dolgozó, más szervezeti egységekben dolgozó munkatársai beülhettek, hogy A vagy B projekt milyen gazdasági eredménnyel zárult, milyen innováció keletkezett benne, milyen tudással, milyen fejlesztési eszközzel oldották meg, milyen problémák voltak az ügyféllel... egyfajta kiértékelése a projektnek. Ez már egyfajta tudásátadást jelenthetne, egy alapot, másrészt olyan jellegü dolgot, hogy ki dolgozott, mit dolgozott benne... akkor már lehetne fogalma a másik szervezeti egységnek is arról, hogy mit tud, még akkor is, ha nincsen meg ez az alap (ti. formálisan megszervezett - kieg. szerzőtől) adatbázis.

A bizalom az aktoroknak - a rendelkezésükre álló információk alapján történő - egymás viselkedésére vagy reagálására vonatkozó olyan elvárása, amely előre látható, megjósolható és kölcsönösen elfogadható.
Akik együtt dolgoznak, vagy egymás ellen dolgoznak, játsszák a maguk kis emberi játszmáit. Van ilyen, hogy valaki tud valamit, és azt, köszöni szépen, megtartotta magának. Én személy szerint kikerülöm azt a pontot, és beszerzem máshonnan. Abban a pillanatban, hogy ez nyilvánvalóvá válik, hogy nála elakadt, a nyílt konfrontációtól kezdve a kikerülésig minden lehet...

A bizalom beigazolódásának, azaz előre jósolhatóságának makro- és mikroszintű okairól beszél valójában Sako, amikor a bizalom három fó típusaként azonosítja a szerződésen alapuló bizalmat (contractual trust), a szakértelmen alapuló bizalmat (competence trust) és a jóindulaton alapuló bizalmat (goodwill trust). A szerződéses bizalom valamilyen írott vagy szóbeli megegyezésen alapul, és azon az általános etikai elváráson nyugszik, hogy a felek betartják ígéreteiket. Ennek lehetnek makroszintű, írott szerződéses formái (munkaszerződések, projektleírások, munkaköri leírások, megbízási szerződések) és szóbeli megállapodásai. A szakértelem a (szakértői) hitelesség forrásaként táplálja a bizalmat, amelyet egyrészt az adott személy képzettsége, megszerzett minősítései igazolnak (makroszint), másrészt az adott helyzetben tanúsított személyes viszonyulása és problémamegoldása. A nyitottságon és emberekbe vetett hiten alapuló jóindulatot általában az emberekbe és a rendszerbe vetett bizalom jellemzi (Sako, 1992). Szerintünk a bizalom ennél öszszetettebb fogalom. A tudástranszfer folyamatában számos olyan tudástartalom van jelen, amely nem vagy nehezen kodifikálható, így konkrét szerződéses megállapodás tárgyaként kevésbé megfogható. Elsôsorban az egyéni mentalitás (bizalomba vetett hit) dominál, amelynek hatékonysága a hitelességtől függ. Ezért a bizalom Sako-féle típusait nem önálló formaként, hanem a bizalom különböző jellemzőjeként értelmezzük, amelynek makroszintű és mikroszintű megjelenési formái vannak. A bizalom mindig valamilyen idődimenzióban történő (múltbeli tapasztalat, jelenidejűség, jövőbeli viszonzás) tranzakció (contractual) részeként van jelen, amelyet alapvetően befolyásol mind a tudásgazda hitele (competence) és nyitottsága (goodwill), mind a tudást átvevő saját szakértelmén alapuló befogadóképessége és nyitottsága. Ezek megléte a bizalom magas szintjét, hiánya a bizalmatlanság jelenlétét reprezentálja.

A bizalom és bizalmatlanság megközelítésünkben nem egyazon dimenzió két oldala, mert ebben az esetben kizárjuk annak lehetőségét, hogy a bizalom és bizalmatlanság egyszerre lehet jelen egy másik aktorral (személy, csoport, szervezet, hálózat) kapcsolatban, holott gyakori jelenség, hogy ugyanahhoz az aktorhoz más viszony köt a jelenlegi sokváltozós környezetben (Jones - George, 1998). A viszonyulás lehet bizonyos helyzetekben: alacsony bizalomigény (megelégszik a rendelkezésre álló információkkal és együttmúködéssel), feltételes bizalom (kalkulatí ${ }^{37}$ háttértől függ) fel- 
tétel nélküli bizalom (kölcsönös azonosulás, erős érzelmi elemek) vagy éppen a bizalmatlanság (gyanakvás) az elővigyázatosságra intő háttértényezők ${ }^{38}$ miatt.

Lehet például egy konkrét személy, akivel egyébként előzőleg jól múködő viszonyban vagy, függelmi kapcsolatba kerül egy olyan valakivel, akinek nem szeretném, ha tudomására jutna az adott információ, és nem szeretném kellemetlen helyzetbe hozni őt sem, meg magamat sem. Ha neki kell visszatartania egy olyan információt, amelyet egyébként kötelessége lenne a függelmi viszony miatt vele megosztani vagy véletlenül elszólja magát. Hát nem ér annyit az egész, inkább kevesebbet mondok, de más munkán, egy másik projektben ez már nem gond.

Értelmezésünk szerint - Lewicki és munkatársai álláspontját alapul véve - a bizalom és bizalmatlanság két, egymástól elkülönülő dimenzión helyezkedik el, amelynek végpontjain az intenzitás mértékei (alacsony, illetve magas) állnak (Lewicki - McAllister Bies, 1998).

A bizalom a másik aktor viselkedésére vonatkozó pozitív elvárások összessége, ahol a magas bizalomszintet érzelmi és gondolati szinten a jóindulat, lojalitás, nyitottság, megbízás, a másik elfogadása jelzi, viselkedés szintjén pedig a kezdeményezés és a kooperáció. Alacsony bizalomszint esetén a másikban való megbízás alacsony szintje, háttérbe vonulás, passzivitás és bizonytalanság jellemzi. A bizalmatlanság a másik aktor viselkedésével kapcsolatos negatív elvárásokra vonatkozik, ahol az alacsony szint jelzi, hogy az érintett aktor nem vár a másik aktortól olyan viselkedést, amely neki hátrányos lenne (éberség hiánya), emellett nem igényli a kívánt viselkedés követhetőségét (monitorozás) és ellenőrzését (kontroll). A magas szintű bizalmatlanság kísérő tényezői a félelem, információ-visszatartás és titkolózás, a szkepticizmus és cinizmus, elővigyázatosság és gyanakvás.

E két dimenzió mentén az erős bizalmi kapcsolatot a magas bizalom-alacsony bizalmatlanság párosítás jellemzi azon helyzetekben ${ }^{39}$, ahol az aktorok kölcsönösen elvárják a másik fél bizalmát, és nem számítanak negatív következményekre.

Sokat számít, hogy aki ilyen (ti. nem vesz részt a tudásmegosztásban - kieg. szerzőtől) az utána menynyire osztja meg (a tudást) utána, amit ő szerzett, avagy csak magáévá teszi és elrakja egy fiókba. Ez nagyon minimális, százból egy...

A tudás nem egyenlő a cselekvéssel. Előfordulhat, hogy a befogadó érti és elsajátítja a tudást, de azt nem használja. Egy lehetséges oka ${ }^{40}$ a tudástranszfer alacsony hatékonyságának az elsajátított tudás figyelmen kívül hagyása, vagy annak csak részleges hasznosítása (Hansen - Haas, 2001). Ez származhat a tudáshordozó iránt tanúsított bizalmatlanságból és a kockázatvállalástól fakadó félelemtől is. Ambivalens viszonyt jelez a magas bizalom-magas bizalmatlanság párosítás, mely a többféle kapcsolatban lévő aktorok összetett helyzetére vonatkozhat (adott területen együttműködő partneri viszony, más területeken versenytárs) egyszerre van jelen az aktorok közötti erős bizalomigény és információ-visszatartás.

A multi (partnerként együttműködő - kieg. a szerzőtől) szakemberei kint voltak a cégnél és nem adták át (ti. a fejlesztési munkához kapcsolódó, már rendelkezésükre álló információt - kieg. a szerzőtől), mert ugye nem mindent adnak át, a partneri viszonynak is megvannak a szintjei... és a legrosszabb abban az esetben történt, ami nem szült személyes ellentétet, mert nem hagytuk elfajulni, hogy mi itt házon belül kikísérleteztünk, tehát felépítettünk egy hasonló rendszert, és másnap az ügyfélhez úgy mentünk ki, hogy mi ezt és ezt tapasztaltuk. Az ügyfél meglepődötten mondta, hogy ez volt benne a leírásban (ti. a multitól kapott ügyfélpéldányban - kieg. a szerzőtől), amit mi nem tudtunk...Nem tudom, mi érdeke származott abból, hogy ezt ne ossza meg, az, hogy ô nem akarta a tekintélyét elveszíteni. Úgy érzem, a konstruktív munkának az a lényege, hogy egyenlő feltételekkel, folyamatos informálással megadják a lehetőséget. Úgy gondolom, hogy ez annak a konkrét embernek volt a hibája, ő ilyen beállítottságú volt. De a multik attól félnek, hogy kiadnak egy tudást és az itteni emberek élni tudnak vele...

A bizalom labilissá válik, ha kevés számú összetevőn ${ }^{41}$ nyugszik, ezért nem eléggé megalapozott és a várakozásokat megcáfoló információ kerül képbe, amely erősebb hatású, mint a közvetett cáfoló információk hiányán alapuló kezdeti megítélés, továbbá nagyon magas a másik félbe vetett bizalom kockázata (McKnight - Cummings - Chervany, 1998). A bizalommal kapcsolatos ambivalencia kezelésére való képesség (optimális bizalom ${ }^{42}$ ) teszi lehetővé a különböző bizalmi szinteket igénylő helyzetek egyidejű kezelését (Hunyady - Székely, 2003). A bizalom megjelenési formáinál fokozati különbségek tapasztalhatók, ezért szükséges megkülönböztetnünk egymástól az eltérő bizalomigényt. Az aktoroknál mást és mást jelent az alacsony bizalomigény és a bizalmatlanság fogalma. Az előbbi származhat abból is, hogy számára a rendelkezésre álló információk elégségesek, és nem igényel további megerősítést, míg az utóbbi esetben erős a bizonytalanság érzése, és nem képes bízni a másik aktorban. 
A személyes bizalom igényének erősödése fokozza a rendszerbe vetett makrobizalom iránti igényt is annak ellenére, hogy azzal részben helyettesítési viszonyban áll. Ez a tendencia általánosan jellemző a kutatásba bevont személyek attitűdjére. Jelen kutatás a tudástranszfer befolyásoló elemeként tekintett tanulástámogatási formák iránti személyes igényen keresztül jelzi a szervezet részéről látni és tapasztalni kívánt (makro)bizalmat.

A tudástranszfer folyamatának jellegzetes formája az azonos csoporthoz tartozó tagok közötti tudásmegosztás. Az egyenrangú partneri viszony során, ahol ténylegesen kétirányú tudástranzakciós folyamat zajlik, nem jellemző az információ-visszatartás. A tudásmegosztás hatékonyságát befolyásolják a - tudásukat megosztó - emberek cselekvését irányító különféle magatartási szabályok és normák (Kocsis, 2004). A tanulásra leginkább akkor van esélye az egyénnek, ha az adott csoportra, amelynek munkájában részt vesz, jellemző a ligitim és periférikus részvétel. ${ }^{43} \mathrm{~A}$ legitimitás a bekapcsolódás módjára, a periférikusság arra a bizonyos távolságra vonatkozik, amely szükséges a tapasztalatokból való tanulásra. A másokkal való formális ${ }^{44}$ és informális ${ }^{45}$ együttműködés egyik legfontosabb feltétele az adott csoporton belüli kölcsönös bizalom. Wenger szerint az ún. tudás- és gyakorlati közösségekben való részvétellel folyamatosan alakul az egyének önmagukról alkotott képe és bizalmi szintje (Wenger, 2000). A közös érdeklődés és érdekeltség csökkenti a bizalmatlanságból fakadó információ- és tudásvisszatartást. Ezek előfordulása a spontán saját kezdeményezésből létrejövő közösségekben ${ }^{46}$ minimális. A másokkal való kapcsolat során megjelenő konfliktusok eltérő módon befolyásolják a tudásmegosztást és a bizalmi szintet (Simons - Peterson, 2000). Formális csoportokban előfordulhatnak a személyközi összeférhetetlenségből, függelmi helyzetből fakadó kapcsolati konfliktusok, amelyek gyengítik a bizalmat. Ez negatívan befolyásolja nemcsak az együttműködés hatékonyságát, hanem a csoporttagok tudásmegosztásban felvállalt kezdeményező ${ }^{47}$ szerepét is. A konkrét megoldandó problémákra és feladatokra vonatkozó kognitív konfliktusok magas bizalmi szinttel járnak, ha a különböző álláspontok megismerésével közelebb jutnak mind egymás, mind a problémák megértéséhez.

- Tapasztal-e csoporton belül vagy kívül információ,illetve tudásvisszatartást?

- Igen, de ez szerintem nem mindig tudatos. Az emberek nincsenek tisztában azzal, hogyha megosztják a tudásukat, nem lesznek kevesebbek...

- Szerintem ez természetes velejárója a közösségnek. Ez nem azt jelenti, hogy visszatartom az informá- ciót, hanem hogy tudom, kik azok, akikhez ha elérnek a dolgok, akkor tőle nehezen mennek tovább. A rivalizálás miatt...

- Nem tartom visszatartásnak azt, ha valaki nem tudja úgy átadni, ahogy azt én szeretném megkapni. Viszont olyat, hogy valakitől folyamatosan kérdeztem és folyamatosan lerázott, olyat nem tapasztaltam. Az nem csapatba való ember, nem ide való.

A tudás visszatartásának domináns oka annak feltételezése a tudáshordozó részéről, hogy több haszna származik az ismeretek felhalmozásából, mint amenynyit a másokkal való megosztásból nyerhet. Ennek a tudásintenzív szervezetekben racionális gazdasági okai lehetnek a versenytársak miatt (versenyelőny eltérő értelmezése), a szervezeten belül viszont fő kihívás annak biztosítása, hogy a tudás megosztása kifizetődőbb legyen, mint a megtartása.

- Mik akadályozzák leginkább a tanulást és a tudás megosztását?

- Lustaság...

- Egyetlen cégnek sem érdeke, hogy te általános tudást szerezzél. Te olyan tudást szerezzél, ami a céget előre tudja vinni... egy képzési központtal sokat beszélgettünk erről, hogy amikor leültek a vállalatok képzési vezetőivel, kihúztak egy csomó részt a zseniális képzési programjaikból, mert nem voltak hajlandók megfinanszírozni, csak azt a speciális tudást, mert jobb lesz a munkaerőpiacon és elmegy (ti. a képzésben résztvevő munkatárs - kieg. szerzőtől)...

- Túlterheltség, emberi gyengeségek, a tudás ugye hatalom, és ha megtartom, hatalmasabb leszek a másiknál.

Az információ- és tudásvisszatartásból fakadó bizalmatlanság visszavezethető az aktorok aszimmetrikus helyzetére, ahol a tudáshordozó úgy véli, ${ }^{48}$ hogy nem kapja meg tudása ellenértékét, azaz:

- a tudás aszimmetriáját feltételezi, miszerint a másik fél nem rendelkezik olyan információkkal (tudással), amire neki a jövőben szüksége lehet,

- vagy ezt szándékosan visszatartja a másik fél (megszegi a reciprocitás normáját),

- nem ismerik el mások a személyét értékes és hiteles tudásforrásként ${ }^{49}$ (szakmai hírnév, mint presztízs a vártnál alacsonyabb mértéke),

- nem respektálja a szervezet közvetlen ${ }^{50}$ vagy közvetett $^{51}$ módon a tudásmegosztásban való közremúködését,

- az altruizmushoz vezető kapcsolatok figyelmen kívül hagyása, illetve akadályozása miatt nincs módja 
élni a mentori rendszerben lévő lehetőségekkel, nem tudja kinek adja át tudását, nem kíváncsiak tapasztalatára.

A tudástranszfer kommunikációs folyamata egyrészt a konkrét adatokon alapuló kifejezhető információn (explicit), illetve a nehezen kodifikálható tudáson (implicit) nyugszik, másrészt a releváns információk hiánya esetén az előbbi tudástartalmak körülményeire vonatkozó feltételezéseken. A bizalom Fukuyama szerint az informálisan jelen lévő közös értékek és normák összességének tekintett társadalmi tôkéből ${ }^{52}$ ered. A normák az általános emberi magatartás során felmerült problémák kezeléséhez nyújtanak információt és jelentősen csökkentik a tranzakciós költségeket. A bizalom az emberek erkölcsös viselkedésére vonatkozó információ értelmezésének mellékterméke (Fukuyama, 1995). Fukuyama számára az emberi természet (hajlamok, készségek) és kultúra olyan tudáshordozó alapok, amelyek hajlamossá teszik az embert a technika kiterjeszkedéséből származó válságjelenségek megoldására. ${ }^{53} \mathrm{~A}$ vállalatok bizalmi hálózatai is a hálózatok általános problémájával küszködnek, azaz kifelé információs szempontból zártak. Habár képesek társadalmi tőkét létrehozni, e kötelékek nem kapcsolják össze alkalmazottaikat más vállalatok munkatársaival (Fukuyama, 2000). Jelen kutatásban nyert tapasztalataink ennél kedvezőbbek, a munkatársak munkaerő-vándorlásával és folyamatos tudásmegosztásával párhuzamosan ez a társadalmi tőke megosztódik, azaz informálisan tovább gyarapodik. Ezen keresztül körvonalazható egy közös értékrend, amelynek fő jellemzői a tudás folyamatos megújításának belső kényszere és az egymással való megosztás miatti személyes bizalom erősödése.

A versenytársainkhoz képest körülbelül ugyanahhoz az információkhoz férünk hozzá a termékekről, a piacról, a vevőinkről, a konkurenseinkről, egymásról. Érdekes módon az ember maga is már elég jól keveredik, mert már mondtam, én is négy különböző informatikai cégnél dolgoztam az elmúlt nem sokkal több mint tíz évben, tehát eléggé egy piacon mozgunk minden értelemben, és ugyanazokból az anyagokból élünk. A különbséget nem az teszi, hogy ki mihez fér hozzá, hanem az, hogy ezt ki hogyan képes felhasználni és kivel kell megosztani... Meg kell tudni találni az általános ismereteken túl azt a néhány speciális dolgot, amiben el akarok mélyülni, és az összes többi ilyen jellegű tudást azt inkább kollégáktól, partnercégektől, másoktól kell bevonni... Beszélek a többiekkel, és ennek során előbukkan, hogy..., hát ti miből tanultok, és ez elterjed, és utána ezt már csak katalizálja az internet..., több százan tudunk kommunikálni.
Magyarországon a vállalatközi kapcsolatok gyengék, és súlyos gondot okoz az üzleti és más - tudományos, oktatási szféra közötti együttműködés hiánya is. A kiváltó okok közé tartozhat a gazdasági átalakulást kísérő általános bizalmatlanság, félelem a bizonytalansággal járó újtól, továbbá nehezíti a kooperációt az információtechnológiai eszközök, illetve használatukhoz szükséges ismeretek hiánya. Az együttműködés elmélyítésének gátja a külső kényszer vagy lehetőség hiánya, a szervezetek nincsenek eléggé rákényszerítve az együttműködésre. Emiatt hiányoznak a kooperáció pozitív tapasztalatai is, így a bizalom (tudatos) tanulására sincs lehetőség (Kováts, 2004). Ez egyéni és szervezeti szinten a tanulás elszigetelődését vonhatja maga után, háttérbe szorítva a szervezetek közötti együttműködés hálózatként való további tanulási kapacitás előnyeit (Kocsis - Szabó, 2000). Az informatikai piac magyar szereplői éles versenyhelyzetben vannak, kevésbé kooperálnak egymással nemzetközi és hazai piacokon. A tudástranszfert is érintő vállalatközi együttműködési zavarok makrobizalmi (szerződések, jogi feltételek) és személyes mikrobizalmi területét egyaránt említették a felmérésben résztvevők.

Egy partneri kapcsolat elismeréséhez és bizonyos pályázatokon való indulás feltétele az, hogy a papír meglegyen. Partneri minősítés címén előírják, hogy (megfelelő számú - kieg. a szerzőtől) vizsgázott szakemberrel kell, hogy rendelkezzen (a hazai informatikai cég. - kieg. a szerzőtől) ,...

A multi szakemberei kint voltak a cégnél... és picit ők közelebb vannak a fazékhoz, amiből az információkat tudják meríteni, gondolok itt ötletelésekre, öszszefüggésekre, ezt nem adták át, mert ugye nem mindent adnak át, a partneri viszonynak is meg vannak a szintjei...

Úgy gondolom, hogy ez annak a konkrét embernek volt a hibája, ő ilyen beállítottságú volt. De a multik attól félnek, hogy kiadnak egy tudást... és az itteni emberek élni tudnak vele.

A kommunikáció és a bizalom szorosan összefüggnek egymással, és kölcsönösen erősítik egymás hatását a szervezetben. A nyílt kommunikáció egyrészt már önmagában feltételezi és megelőlegezi a bizalom egy szintjét, másrészt mintát mutatva bizalmat kelt. Bizalom hiányában információkat tarthatnak vissza egymástól, vélt vagy valós előnyök érdekében.

\section{Tanulástámogatási formák és a bizalom}

A tudásalapú szervezetek gondolkodásának középpontjában a humán erőforrás tanulási képessége áll. A teljesítményorientáltság miatt nagyfokú rugalmasság 
és önállóság jellemzi a működést, új minták elsajátítására, további lehetőségek feltárására törekszik. Tudatos információmegosztásos kultúra jellemzi. A tanulás magtevékenységként van jelen, amely általánosan kiterjed a szervezeti tagokra és a külsős partnerekre. A tanulás intézményesülésének számos formája megtalálható keretein belül, mert a hangsúly a tudás megosztásán és az együttműködésen van. A tanulási stratégiák a tudástranszfer (termékekben, folyamatokban) és tudásdiffúzió (szervezeti határokon kívüli hálózatok és kapcsolatok) közvetítői. Minél rejtettebb az adott tudás, annál nagyobb előnyt biztosít az azt tudatosan alkalmazó egyén és stratégiai elemként használó szervezet számára (Nonaka, 1994).

A személyek és szervezetek a kölcsönös függés bonyolult hálózataiban müködnek és szükségük van egymásra. A bizalom segítségével tudják kifejezni azt, hogy számítanak egymásra. Általános gazdasági jellemző, hogy növekszik a változatosság és összetettség, különböző kulturális és etnikai háttérrel rendelkező gazdasági szereplők (ember, csoport, szervezet, hálózat) kerülnek kapcsolatba egymással. E különbözőség miatt a hasonlóságon, közös háttéren, értékeken és normákon nyugvó kölcsönös vonzódás csökkenhet, amelyet az egymás iránti bizalom erősítésével ellensúlyozni lehet (Mayer - Davis - Schorman, 1995).

A mások iránt érzett bizalom kifejeződhet a tudásmegosztást támogató szervezeti körülmények megítélésében. Többségben vannak azok a személyek, akik a további bizalom megelőlegezéseként - további tanulástámogatási formákat igényelnének szervezeti részről (1. ábra). Elemzésünk ${ }^{54}$ során a tudástranszfert támogató személyes bizalom (trust) megjelenítéseként kezeltük a minden munkatárs számára hozzáférhető oktatási, fejlesztési és karrier-tanácsadást, a tapasztalatokat megosztó és tudásbővítő személyre szabott egyéni és csoportos formákat és az együttmúködést támogató belső tréningeket. Kiindulópontként az e formákban megjeleníthető elsődlegesen implicit tudástartalmakat vettük. Fontosnak tartjuk megemlíteni, hogy ezek formális szervezése és rendelkezésre bocsátása pusztán kereteket adhat, a tényleges transzfer a benne résztvevők bizalmi szintjén, tudásán és kommunikációján múlik. Rendszerorientált bizalom (confidence) iránti igényként azonosítottuk a szervezeten kívüli (internet) és belüli adatbázisokhoz való hozzáférést, valamint a korrekt tájékoztatást normaként kezelő szervezeti szabály- és normarendszert. E csoportosítás alapja a kodifikálható és aggregálható explicit tudás. Az egyének tanulási törekvéseiben dominánsan van jelen a bizalom iránti igény, ezen belül elsősorban a személyes kapcsolatokra jellemző trust (mikrobiza- lom) megjelenési formáit preferálják, ezt követi a kodifikációs tudásmegosztást támogató technológiai keretfeltételekbe vetett bizalom a confidence (makrobizalom).

1. ábra

Bizalom erôsítésének igénye tudástranszfer támogatáson keresztül

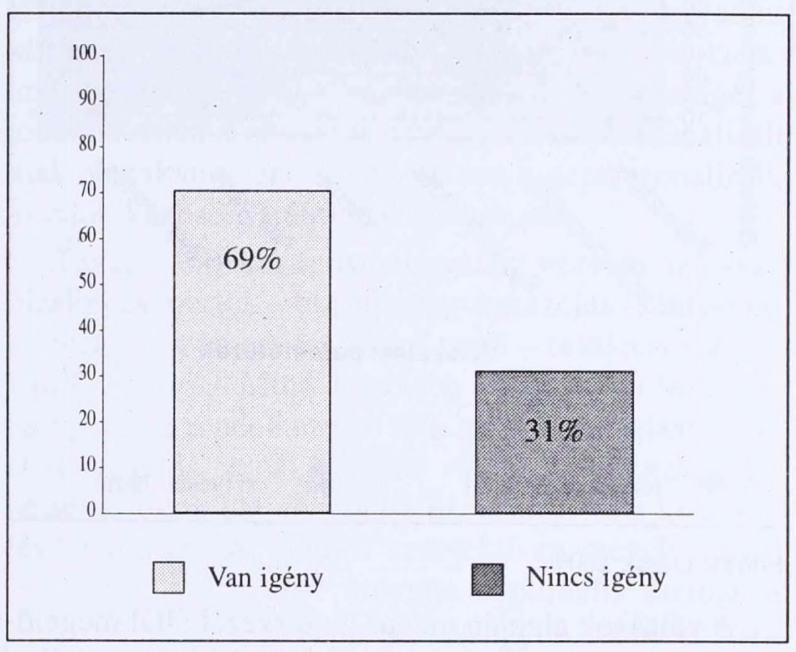

Forrás: Garaj, 2004

A bizalom megjelenítésére - az egyénileg igényelt tanulástámogatási formákat alapul véve - a következő négy csoportot különítettük el:

1. Teljes körű bizalmat igénylők (Teljes-csoport): mindazok, akik egyaránt preferálták a személyes kapcsolatokat és a szervezet által biztosított rendszerorientált tudástranszfer támogatási formákat (vizsgált populáció 36\%-a).

2. Személyorientált mikrobizalmat igénylők (Trustcsoport): akik, elsôsorban a személyes együttmúködést igénylik (vizsgált populáció $25 \%$-a).

3. Rendszerorientált makrobizalmat igénylők (Confidence-csoport): akik a szervezet által rendelkezésre bocsátott támogatásokkal élnének (vizsgált populáció 8\%-a).

4. Nem igényelnek a tudástranszferrel összefüggő további bizalmat (Nem igénylő csoport): akik nem várnak el szervezeti támogatást (vizsgált populáció $31 \%$-a). Ennek oka lehet, hogy egyrészt az érintettek bizalomszintjének megfelelő a rendelkezésre álló tudástranszfer, másrészt bizalmatlanok a szervezet, saját munkatársaik, vezetőik iránt. A kapott eredmények elsősorban az első feltételezést valószínűsítik, miszerint a vizsgált szervezetekben a munkatársak magasabb arányban élhetnek egyes tudástranszfert támogató formákkal, mint amenynyien igényelnék azokat (2. ábra). 
2. ábra

A tudástranszfer-támogatás megítélése

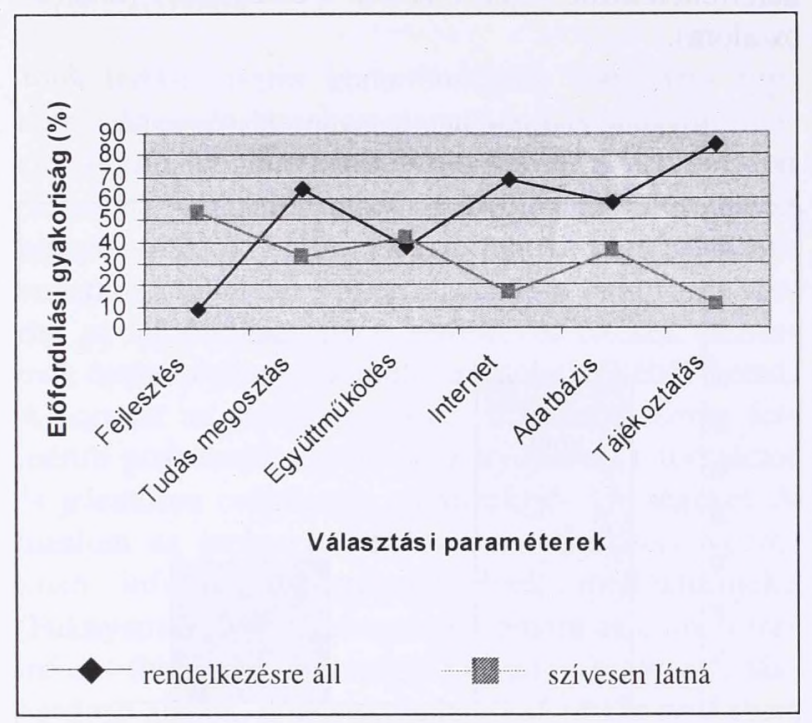

Forrás: Garaj, 2004

A válaszok alapján magas a szervezet által megelőlegezett bizalom az informatikai eszközök rendelkezésre bocsátásával (internet), a szervezeti tudásként megjelenő tudáshordozók (adatbázisok) kezelésével és normaként való megjelenésével kapcsolatban (tájékoztatás). A tudásmegosztó formáknál a kodifikálható tudástartalmakat tartalmazó írásbeli beszámolóknál fontosabbnak tekintik a - megközelítésmódtól, módszerektől, szemlélettől, módszerektől függő - nem leírható tudás megosztását. Az erre irányuló igény fejeződik ki abban, hogy minden harmadik személy szívesen látna még több implicit tudást a szervezetben. Ez magas bizalomszintre és nyitott szemléletmódra utal. Biztos abban, hogy van mit tanulni másoktól és érdekli ezek egyéni és szervezeti hasznosíthatósága.

Nincsen közös munkánk, tehát ebből a tanulás szempontjából is, nemcsak gazdaságilag, az üzletágak szeparáltak maradnak, a tudás az üzletágon belül marad.

Legnagyobb igény a munkatársak, mint munkavállalók részéről a fejlesztésre, oktatásra, karrier-tanácsadásra és az együttműkỏdések támogatására van. A munkatársak az adott szervezet irányukban tanúsított bizalmatlanságának jeleként élhetik meg az ilyen irányú egyéni igények figyelmen kívül hagyását, ha a tudásmegosztás folyamatát szervezetileg generalizált félelmek akadályozzák.

Egyetlen cégnek sem érdeke, hogy te általános tudást szerezzél. Te olyan tudást szerezzél, ami a céget előre tudja vinni. Egy képzési központtal sokat beszélget- tünk erről, hogy amikor leültek a vállalatok képzési vezetőivel, kihúztak egy csomó részt azok zseniális képzési programjaikból, mert nem voltak hajlandók finanszírozni, csak azt a speciális tudást, mert (ti. tartottak attól, hogy - kieg. szerzőtől) jobb lesz a munkaerőpiacon és elmegy.

A kutatásban megvizsgáltuk a tudásmegosztásban részt vevő aktorok információigényét és kockázatvállalási hajlandóságát, továbbá ezek néhány összefüggését az érintett négy bizalomcsoportban. Áttekintettük, hogy mennyire igényelnek különböző információforrásokat, és mennyire szeretnek minél több alternatívát figyelembe venni, mielőtt bármilyen döntést hoznak. Az információhiányból eredő bizonytalan helyzetek kezelésére utal a kockázatvállalás mértéke. A bizalom számottevő kockázatot rejt. $\mathrm{Ha}$ az egyik aktor alkalmazza, és a másik nem, az utóbbi hátrányosabb helyzetbe kerülhet, a jó szándék feltételezésével kiszolgáltatottabbá válik. Ha egyik aktor sem számíthat a másik jóindulatára, a gazdasági folyamatok költségei jelentősen megnövekedhetnek. Ha kölcsönös a bizalom, etikusak a felek és a sajátjukon kívül a közvetlen társas környezetük érdekeit is szem előtt tartják, komoly esély teremtődik a gazdaság hatékonyabb múködtetésére (Hunyady - Székely, 2003). A bizalmat a kockázatvállalás egy speciális formájaként is értelmezhetjük, ahol a kockázatvállalásnál a lehetséges pozitív kimenetel vonzóbb, mint a lehetséges negatív következmény. A bizalomban a szubjektív valószínűség és befolyásoló tényezői (saját és mások tapasztalatai, hajlam, világlátás) jutnak szerephez (Deutsch, 1985). A bizalom mint hajlandóság a másik féltől függő sebezhetőség (vulnerabilitás) vállalására azon az elváráson alapul, hogy a másik fél az elvárt módon viselkedik. Ez önmagában még csak hajlam, nem kockázatvállalás. A kockázatvállalás konkrét szituációtól függ, ${ }^{55}$ a bizalom iránti hajlam általános személyiségvonás az adott személyhez kötődik. Kockázatosnak az ebből eredő bizalomteli viselkedés tekinthető (Mayer - Davis - Schorman, 1995).

Kutatásunkban a válaszadók többsége kezdeményezőként lép fel az információkezelésben, ezen belül a tudásmegosztásban, ahol mások álláspontjának, tapasztalatainak megismerésére törekszenek. Ez a tudástranszfer iránti erős elvárást jelzi, azaz a válaszadók 20\%-a vállal kockázatot, a többség minél több tudástartalom elsajátítására törekszik (3. ábra).

Ezt a felismerést erősíti meg fenti tényezők korrelációvizsgálata (1. táblázat). A bizonytalan helyzetben döntésre kényszerülők igyekeznek minél inkább csökkenteni az információhiányból fakadó kényszert. 
3. ábra

Bizonytalanságkezelés és információigény

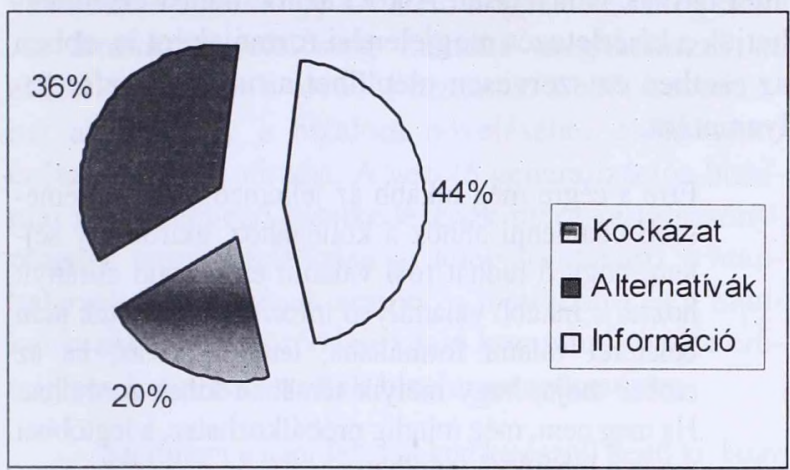

Forrás: Garaj, 2004

Magas szintű bizalom jellemzi őket, amely kifejeződik a személyközi bizalomban (sok alternatíva) és a rendszerorientált bizalomerősítő intézmények használatában (információforrások) a vizsgált teljes populációban.

Az információkezelés korrelációs táblázata az összes bizalmi csoportban $(\mathrm{N}=4)$

\begin{tabular}{|c|c|c|c|c|}
\hline \multicolumn{2}{|c}{ Correlations } & $\begin{array}{c}\text { Kockázat } \\
\text { vállalás }\end{array}$ & $\begin{array}{c}\text { Sok } \\
\text { alternatíva }\end{array}$ & $\begin{array}{c}\text { Több infor- } \\
\text { máció forrás }\end{array}$ \\
\hline \multirow{2}{*}{$\begin{array}{c}\text { Kockázat } \\
\text { vállalás }\end{array}$} & Pearson Correlation & 1,000 &, 546 &, 809 \\
\cline { 2 - 5 } & Sig. (2-tailed) &, &, 454 &, 191 \\
\cline { 2 - 5 } & $\mathrm{N}$ & 4 & 4 & 4 \\
\hline \multirow{2}{*}{$\begin{array}{c}\text { Sok } \\
\text { alternatíva }\end{array}$} & Pearson Correlation &, 546 & 1,000 &, 896 \\
\cline { 2 - 5 } & Sig. (2-tailed) &, 454 &, &, 104 \\
\cline { 2 - 5 } $\begin{array}{c}\text { Több } \\
\text { információ } \\
\text { forrás }\end{array}$ & N & 4 & 4 & 4 \\
\cline { 2 - 5 } & Pearson Correlation &, 809 &, 896 & 1,000 \\
\hline
\end{tabular}

Forrás: Garaj, 2004

Az egyes tényezőknek a makrobizalom (confidence) és mikrobizalom (trust) formákhoz való szoros viszonyára ${ }^{56}$ utal a 4. ábra. Eszerint a személyközi bizalom nagyobb biztonságérzettel jár, ezért inkább hajlamosak indokolt esetben a kockázatvállalásra. Ez kevésbé jellemző a rendszerorientált bizalomnövelő mechanizmusokat elvárók körében. Minkét bizalomtípus körében kiemelten nagy igény van mind az információforrások használatára, mind a sok alternatíva preferálására. Ez a tudástranszfer-támogatás és a bizalomigény jelentős összefüggését mutatja (60\% fölötti). Minden emberre jellemző a generalizált bizalom ${ }^{57}$ bizonyos szintje, amely alapja a konkrét helyze- tekben tanúsított bizalomnak. A bizalom közvetlen személyes interakciókban jelenik meg (perszonalizált mikrobizalom). A makrobizalom a bizalom deperszonalizált változata, ami nem igényel közvetlen tapasztalatot vagy információt az adott aktorról. Alapja egy, a közösség által közvetített norma, szabályrendszer, amelyet minden érintettnek el kell fogadnia, így e szabályok keretei között a tagok egymásban megbízhatnak. Egy adott közösség (csoport, szervezet, hálózat) tagjairól kialakuló benyomás erősen minősíti az adott közösséget a többi potenciális aktor szemében. Ezért a perszonalizált makrobizalom jelentős hatással van a deperszonalizált, az adott közösség iránti makrobizalomra.

További érdekes felismerésekhez vezetett az egyes bizalomcsoportok - bizonytalanságkezelés és információigény viszonyulását alapul vevő - részletes vizsgálata ${ }^{58}$ (5. ábra). Minél közelebb áll az egyén bizalomigényéhez a rendelkezésre álló szervezeti tudástranszfer-támogatás, annál kevésbé vállal kockázatot. A lehetséges okok két végpontja azonosítható, a közöttük lévő változatokat számos szubjektíven megélt ténye-

1. táblázat ző ${ }^{59}$ árnyalja. Optimális esetben a szervezet és az egyén között kölcsönösen magas bizalom van, a tudástranszfer az aktorok igényének megfelelően nagy hatékonyságú, ezért ritkán kényszerülnek indokolt kockázatvállalására. Abszolút negatív helyzetben nagyon alacsony bizalmi szinttel rendelkezik az egyén és a szervezet, ezért jellemző az információ-visszatartás. A tudástranszfer a bizalmatlanságot erôsítő objektív és szubjektív környezeti tényezők miatt alacsony hatékonyságú. Kockázatot ilyen körülmények között még indokolt esetben sem vállalnak, pedig az információhiány és a tudásvisszatartási zavarok miatt ezek aránya magas. Eredményeink a pozitívabb kicsengéshez állnak közelebb.

Erre utalnak az információforrásokra vonatkozó választások, amelyek nagyon hasonlóan alakulnak minden egyes csoportban (60-80\% közötti). A legkevésbé kockázatot vállaló, további bizalmat kevésbé igénylők csoportjához tartozók is nagy számban igénylik a másoktól származó alternatívákat, ez a tudástranszfer minél hatékonyabb működtetésének igényét jelzi. A rendszerorientált makrobizalmat igénylők csoportja (confidence) igényli relatíve legnagyobb arányban ${ }^{60}$ a sok alternatívát. Ennek hátterében a szervezettől elvárt formális tudástranszfer-támogatások iránti magas igény áll. 
4. ábra

Bizalomigény és információkezelés

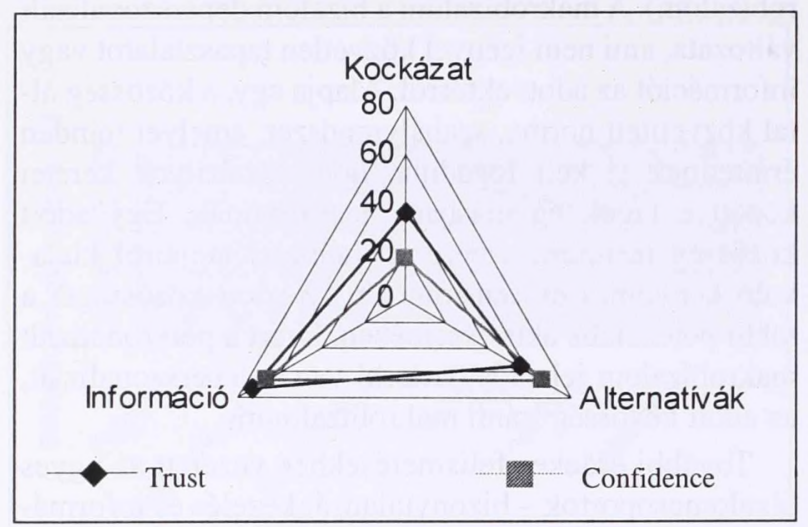

Forrás: Garaj, 2004

5. ábra

Bizonytalanságkezelés és információigény eltérő bizalmi csoportokban

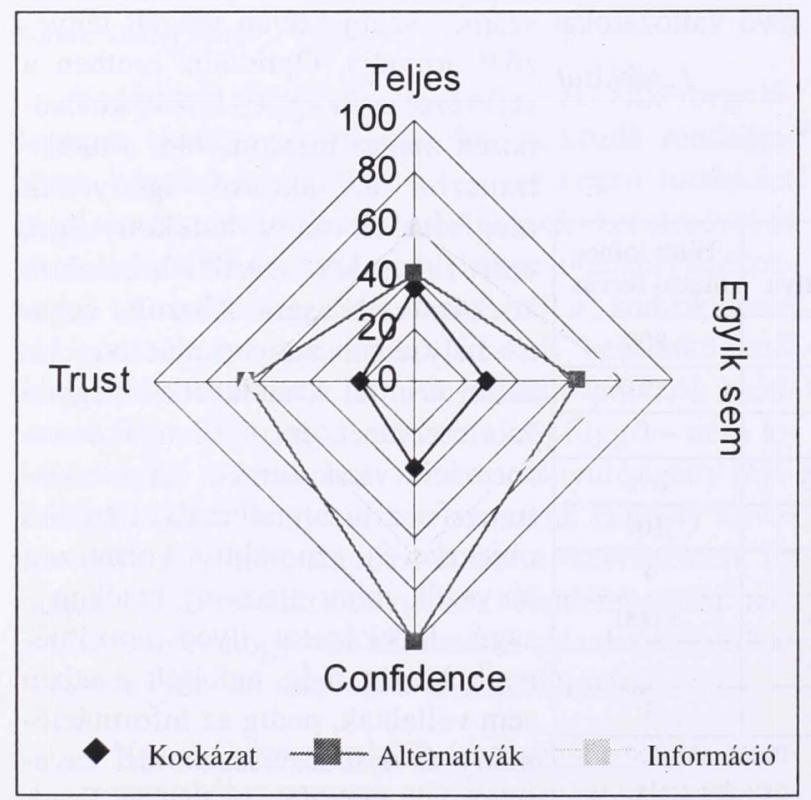

Forrás: Garaj, 2004

Nagyon önállóan működnek az üzletágak. Ennek van egy rossz kimenete, ami egyfajta kapacitáshiány, nincsen olyan tudásbázis vagy adatbázis, amiben a meglévő tudásainkat felhalmozzuk, másrészt pedig nincs nyilvántartva igazán az, hogy melyik ember mit tud, ezért nem tudjuk igénybe venni a másik üzletágnak, pedig nagyon szeretnénk az ilyen irányú szabad kapacitását.

Legnagyobb előfordulási arányt ${ }^{61}$ képvisel - ezért a legjellemzőbbnek tekinthető - a teljes körű bizalmat igénylők csoportja. Ennek kockázatvállalási szintje a legmagasabb, megközelíti a tudásmegosztást igénylő alternatívák választását. A kockázatvállalást értelmezhetjük a kísérletezés megjelenési formájaként is, ebben az esetben ez szervesen ráépülhet a tudástranszfer folyamatára.

Erre a cégre még inkább az jellemző, hogy érdemesebb odamenni ahhoz a kollégához, akiról úgy sejtem, hogy ô tudhat róla valamit és ő majd elirányít hozzá... Inkább valamilyen informális kezdetek után beleterel valami formálisba, tényleg jó az, ha az ember tudja, hogy melyik témában kihez fordulhat. Ha meg nem, még mindig próbálkozhatsz, a legtöbbet úgyis a hibáidból tanulhatsz.

A szervezeten belüli bizalom döntően a vezetők befolyásoló képességén ${ }^{62}$, jóindulatán ${ }^{63}$ és szabálykövető integritásán ${ }^{64}$ múlik, és a szervezeti célok elérhetőségébe vetett hitben mutatkozik meg. A szervezet iránti bizalom függ a kommunikációs folyamatoktól, a vezetői magatartástól, az alkalmazottak döntéshozatalba való bevonásától és a munkavégzés csapatjellegétôl is. A mások (egyes munkatársak, csoportok) bevonására építő participatív vezetési stílusok iránti igény növekedése is a bizalomra irányítja a figyelmet. A bizalmi alapú módszerek közé tartozik a személyre szabott támogatás és szervezeti jövőképnek megfelelő viselkedési modell. A vezetői döntések megítélésében a neutralitás ${ }^{65}$ mellett a bizalom is meghatározó. A vezetővel kapcsolatos személyes bizalom erősödését gátolja az irányító-számonkérő kommunikációs stílus, mert információszűrésre késztetheti a munkatársat. A facilitáló-támogató magatartás nemcsak az információáramlást segíti, hanem erősíti a bizalmat is.

Empatikus képességekre is szükség van, bele kell tudni érezned magad akár a kollégáid, akár a főnökeid lelkivilágába, mert vagy össze fogsz veszni a kollégáiddal, vagy megharagszol a főnöködre, vagy ő haragszik meg rád, mert nem tartottad be azokat az eljárási lépéseket, amiket ő megkövetel, amiben nem biztos, hogy mindig logikus elemek is vannak...

Volt korábban egy főnököm, szintén informatikai cégnél, aki azt mondta, hogy szántanunk kell ahhoz, hogy arathassunk, és ezt csinálta is. Egy évben egyszer el kellett menni tanulni, mondjuk egy ötnapos tréningre. Mivel ez rendszeresen ismétlődött, szerintem még jobban rögzültek a dolgok, mert ki tudtuk próbálni, mi az, ami múködik a gyakorlatban...

Tipikus vezetői kihívás a bizalom és a kontroll dilemmája, azaz mekkora felelősséget lehet és szükséges 
egy munkatársra átruházni. A bizalom és bizalmatlanság ebben az értelemben a munkatársak szubjektív vélekedése arról, hogy a vezető hogyan ítéli meg őket. $\mathrm{Az}$ átruházott felelősség mértéke meghatározza az elköteleződést és a további bizalmat. Ebből következhet az is, hogy a bizalom növeléséhez csökkenteni érdemes az ellenőrzést. A vezető generalizációs bizalmat megelőlegező viselkedésének mértéke (alacsonymagas), vezetői felfogása a (delegáló-utasító), a munkatársak bevonásának aránya, a jóindulatra és a munkatársakkal való törődésre utaló kommunikációja erőteljesen hat a beosztottak bizalompercepciójára.

Szerintem a napi feladatokon keresztül derül ki, hogy mennyire vannak tisztában a főnökök X képességeivel, nem biztos, hogy mindig tisztában vannak vele... Egy valós probléma, azok a főnökök, akik az adott részlegeket vezetik, irányítják, mennyire tudnak olyan körülményeket, olyan feladatokat biztosítani, hogy a három diplomával rendelkező munkatársak ne csak szövegszerkesztővel jelentéseket írogassanak, hanem tényleg kutatással-fejlesztéssel kapcsolatos eredményeket tudjanak elérni és legyen idejük és energiájuk saját tapasztalataikat átadni...

A mai napig megvan, hogy ha gondod van, mehetsz a közvetlen vezetődhöz vagy a cégvezetőhöz. Nem lett zárkózottabb, vagy nem lettek letiltva utak, csak ő már inkább a saját vezetőivel foglalkozik, ők pedig a saját embereikkel... Belső ötletelés eredménye volt a terjeszkedés, leült 18 ember és végig beszélte, hogy mi legyen... A szakmai képzéseket a közvetlen fönök mérlegelheti, egyébként a vezetőség döntheti el..

\section{Összegzés}

Kutatásunk szerint a szervezet iránti bizalmat befolyásolja a tanulástámogatási formák rendszere az egyéni tanulási igényektől függően. A munkatársak a tanulást és tudásmegosztást hangoztató szervezeti HR személyzetfejlesztési és képzési politikától azt várják, hogy a szervezet érzékenyen reagáljon a szervezeti célokkal összhangban lévő egyéni tanulási igényekre, és ennek megfelelően alakuljanak a tânulástámogatási formák is. Amennyiben ez a visszacsatolás hiányzik, csökkenni fog a bizalom az ezért felelős személyek (vezetők) iránt. Ezért a tudástranszfert támogató rendszer észlelése és értelmezésének pontossága ugyanúgy meghatározója a szervezet iránti bizalomnak, mint maga a rendszer. A szervezet iránti bizalmat valóban növeli - eredményeink szerint - egy relevánsabb, a tanulástámogatási formákra visszaható HR rendszer bevezetése, elsősorban a tudástranszfer céljából igé- nyelt személyközi kapcsolatok megerősítésén keresztül. Kutatásunknak a bizalomra vonatkozó következtetése elsősorban a bizalmat befolyásoló tényezők idioszinkratikus ${ }^{66}$ és kontextusfüggő jellegét támasztja alá.

Eredményeink alapján kijelenthetjük, hogy a bizalom megfelelő szintje szükséges, de nem elégséges a tudástranszfer hatékony működésének. A bizalom elsősorban szubjektív feltételként van jelen, amelyet bizonyos makrobizalmi mechanizmusokkal helyettesíteni tudunk a tudásmegosztás szervezeti szintjén, de nem pótolhatja a személyek közötti tudást. Hiába van bizalom és a szükséges tudást hordozó aktor, ha probléma van a kommunikáció és információfeldolgozás, azaz kódolás és dekódolás szintjén. Ezért e három tényező, vagyis bizalom, tudás és kommunikáció szerepét tartjuk kulcsfontosságúnak és fejlesztendőnek. A gazdasági szereplők viselkedése - ezen belül tudása, kommunikációs képességei és másokban való megbízása - meghatározott szocializációs folyamat során formálódik. Az aktorok bizalomhoz való viszonya nem statikus, ezért akarva-akaratlanul hatnak egymás mentalitására. Végül, de nem utolsó sorban bízunk abban, hogy a bizalom, tudás és kommunikációs hatékonyság növelésének - a különböző etikai-kulturális háttérre is tekintettel lévő - alternatív lehetőségei és további öszszefüggéseik vizsgálata a társadalmi-gazdasági fejlődés egyik támogató eszközévé válik a jövőben.

\section{Felhasznált irodalom}

Ackermann, E. (1995): Construction and Transfer of Meaning Through Form. In: Steffe, L. - Gale, J. (ed), (1995): Constructivism in Education. Lawrence Erdbaum Associates, Hillsdale, New Jersey. 341

Arrow, K. J. (1973): Information and Economic Behavior. Fede ration of Swedish Industries. Stockholm

Bőgel György (2004): Informatikai beruházás - üzleti megtérülés. Tézisek. Forrás: http://www.econ.klte.hu/oktatas_es_kutatas/ habilitacio/bogel_tezisek.pdf letöltve: 2004. október 19.

Carlsson, B. - Eliasson, G. (1991): The Nature and Importance of Economic Competence. IUI Working Paper No. 294. Stockholm

Csányi Vilmos (1999): Az emberi természet. Humánetológia. Vince Kiadó, Budapest

Davenport, T. H. - Prusak, P. (2001): Tudásmenedzsment. Kossuth, BKE Vezetőképző Intézet, Budapest

Delhey, J. - Newton, K.: Who Trusts? The Origins of Social Trust in Seven Nations. http://www.colbud.hu/honesty-trust/delhey/pub01.pdf letöltve: 2004. december. 5.

Deutsch, M. (1985): Distributive Justice: A Social Pychological Perspectieve. New Haven, Yale University Press

Falus Iván - Ollé János (2000): Statisztikai módszerek pedagógusok számára Okker Kiadó, Budapest

Florida, $R$. (2004): The Rise of the creative class Basic Books. New York. http://www.adobe.com/products/acrobat/readstep2.html letöltve: 2004. október 25. 
Fukuyama, F. (2000): A nagy szétbomlás. Európa Kiadó, Budapest Fukuyama, F. (1995): Trust: The Social Virtues and the Creation of Prosperity. Hamish Hamilton. London

Garai László (2003): Identitás-gazdaságtan - Gazdaságpszichológia másképp. Tas Kiadó, Budapest

Garaj Erika (2004): Tanulás és identitás az információgazdaságban - Egy empírikus kutatás tapasztalatai a magyar informatikai szektorban. OTKA 40768. számú kutatás munkaanyaga. Információgazdaság és Identitás Tudományos Iskola, Budapest

Hansen, M. T. - Haas, M. R. (2001): Different Knowledge, Different Benefits: Toward a Productivity Perspective on Knowledge Sharing in Organizations. Academy of Management Procedings. pp. 1-6.

Hámori Balázs (2003): Érzelem-gazdaságtan - A közgazdasági elemzés kiterjesztése. Kossuth Kiadó, Budapest

Hámori Balázs (2004): Bizalom, hírnév és identitás az elektronikus piacokon. Közgazdasági Szemle LI. évf. szeptember pp. 480-497.

Hámori Balázs - Szabó Katalin (2004): A piaci algoritmusok és magatartásformák változásai az információgazdaságban. In: Czagány László-Garai László (szerk.), (2004): A szociális identitás, az információ és a piac. SZTE Gazdaságtudományi Kar Közleményei. JATEPress, Szeged pp. 43-78

Hayek, F. A. (1948): The Use of Knowlegde in Society. In: Individualism and Economic Order. Chicago. University of Chicago Press

Hunyadi György - Székely Mózes (szerk.) (2003): Gazdaságpszichológia. Osiris Kiadó, Budapest

Jones, G. R. - George, J. M. (1998): The experience and evolution of trust: Implications for cooperation and teamwork. Academy of Management Review. 23. 3 Vol. pp. 531-546.

Klang, M. (2001): Who do you trust? Beyond encryption, secure ebusiness. Decision Support System, Vol. 31. Issue 3. August. pp. 293-301

Kocsis Éva (2004): A tudásmegosztás hatékonysága. Menedzseri szemlélet versus gazdaságelméleti megközelítés. Társadalom és Gazdaság, 26. évf. 1. sz. pp. 39-55.

Kocsis Éva - Szabó Katalin (2000): A posztmodern vállalat. Tudás és hálózatosodás az új gazdaságban. OKM. Bp.

Kornai János: Tisztesség és bizalom a poszt-szocialista átmenet fényében. Gondolatok a Collegium Budapest „Honesty and Trust" kutatásának alapján http://www.colbud.hu/fellows/kornai_publ/kornaiho.doc letöltve: 2004. december 5.

Kováts Gergely (2004): Esettanulmány egy magyar szoftverfejlesztô hálózatról. Munkaanyag STILE (Statistics, Indicators, Labour Market, eEconomy) project. (Koordinator: Mako Csaba) MTA Szociológiai Kutatóintézet, Budapest (A szerző szíves hozzájárulásával)

Lam, A. (1998): Tacit Knowledge, Organisational Learning and Innovation: A Social Perspective. DRUID Working Paper pp. 98-122. Copenhagen

Lewicki, R. J. - McAllister, D. J. - Bies, R. J. (1998): Trust and distrust: New relationships andrealities. Academy of Management Review, 23. 3. Vol. pp. 438-458.

Mayer, R. C. - Davis, J. H. - Schoorman, F. D. (1995): An integrative model of organizational trust. Academy of Management Review, 20. 3. Vol. Pp. 709-734.

McCormick, D. (1997): An essay on the origin of the rational utility maximalization hypothesis and a suggested modification. Eastern Economic Journal, Vol. 23. Issue 1. Winter. pp. 17-40.

McKinght, D. H. - Chervany, N. L. (2001): Conceptualizing Trust: A Typology and E-Commerce Customer Relationships Model. Proceedings of the 34th Hawaii International Conference on System Sciences. IEEE
McKnight, D. H. - Cummings, L. L. - Chervany, N. L. (1998): Initial trust formation in new organizational relationships. Academy of Management Review, 23. 3. Vol. pp. 473-490.

Nonaka, I. (1994): A dynamic theory of Organizational Knowledge Creation. Organization Science Vol. 5. January, pp. 11-37

Örkény A. - Csepeli Gy. - Székelyi M. - Barna I. (2003): Blindness to Success: Social psychological objectives ont he way to market economy in Eastern and Central Eurpoe. Collegium Budapest. http://www.colbud.hu/honesty-trust letöltve: 2004. december 10 .

Perelman, M. (1998): Information, Social Relations, and the Economics of High Technology. Mac Millan

Polányi Mihály (1994): Személyes tudás I-II. Atlantisz Kiadó, Budapest

Putnam, R. D. (1994): Making demokracy work. Princeton University Press, Princeton

Sako, M. (1992): Prices, Quality \& Trust: Inter-firm Relations in Britanian and Japan. Cambridge University Press

Simons, T. L. - Peterson, R. S. (2000):Task conflict and relationship conflict in top management teams:The pivotal role of intragroup trust. Journal of Applied Psychology. 83. 1 Vol. pp. 102-111.

Sveiby, K. E. (2001): Szervezetek új gazdasága: a menedzselt tudás. Budapest, KJK Kerszöv

Swanstrom, E. (1999): Metaknowledge and Metaknowledgebases. In: Liebowitz, J. Knowledge Management Handbook. London. CRC Press

Szabó Katalin - Kocsis Éva (2003): Tanulás és felejtés vegyes vállalatokban. Oktatási Minisztérium, Budapest

Wenger, E. (2000): Communities of practice and social learning systems. Organization, Vol. 7. No. 2. pp. 225-245

Williamson, O. E. (1998): Transaction Cost Economics: How It Works. Where It Is Headed. De Economist, No. 146. pp. 23-58.

Woodruff, C. (2003): Establishing Confidence in Business Partners: Courts, Networks, and Relationships as Pillars of Support. Collegium Budapest http://www.colbud.hu/honestytrust letöltve: 2004. december 11

\section{Lábjegyzetek}

1 A tudástranszfer fogalmát szinonímaként kezelem a tudásmegosztás, illetve -átvitel fogalmakkal.

2 ,Trust is crucial wherever risk, uncertainty, or interdependence exist" idézi: McKnight-Chervany (2001) 1. old.

3 A felmérés az Információgazdaság és Identitás Tudományos Iskolában készült, az OTKA 40768. számú kutatás keretében 2004 őszén. Kutatásvezetôk: Hámori Balázs, Szabó Katalin. Az empirikus kutatás tárgya: Identitás és tanulás a hazai informatikai szektorban.

4 Öt szervezetben összesen: öt szervezeti kérdőiv, 45 egyéni kérdőív, 22 mélyinterjú (szervezetenként 4-5 fővel).

$5 \mathrm{Az}$ adatelemzés a Windowsxp Excel programja (leíró statisztikai eredmények kiszámítása és ábrázolása) és néhány esetben SPSS 9.0 for Windows verziója alkalmazásával történt.

${ }^{6}$ Kvale (1996) alapján: 1. Nyílt, leíró kérdések (belsổ és külsố folyamatok bemutatására), 2. Szondázó kérdések (hipotetikus megértés megerốsítésére vagy cáfolására), 3. Specifikus kérdések (pontosításra), 4. Konfrontatív technika (saját álláspont kifejtésére), 5.Reflektív kérdések (mélyítés), 6. Aktív figyelem (viszonyulások erôsítése, visszajelzés). Pl. Tapasztal-e a szervezeten belül vagy kívül információ illetve tudás-visszatartást? Mi lehet ennek az oka? Kell-e számolnia az újítóknak vagy a környezetüknél nagyobb tudással rendelkezőknek irigységgel, 
ellenséges attitűddel, betartással? Miért? Melyek azok a tényezők (emberi, szervezeti, tárgyi) tapasztalatai szerint, amelyek leginkább akadályozzák a tanulást és a tudás megosztását? Tapasztalt-e olyan jelenséget, hogy a tudás birtokosai visszaélnek a partnerek információhiányával?

7 A kutatás során összesen: 5 szervezeti kérdőív, 45 egyéni kérdôív és 22 mélyinterjú készült.

8 Biológiai, evolúciós, jelenség, kulturális akkor fordul elő, ha valamilyen szelekciós hatás egy tulajdonságot optimális paraméterein túl, minden korlát nélkül változtat, megnövel. Ilyen pl. státusok vétele, hatalmi versengés, dominancia, érdemtelen kiváltságok elnyerése Bővebben: Csányi (1999) 284-291. oldal.

9 Olyan rögzült szokások, amelyeket arra használunk, hogy megvédjük magunkat a gondolataink feltárásából származó kényelmetlenségektől vagy fenyegetettség érzéstôl (pl. hozzáértés, hitelesség megkérdőjelezése miatt).

10 Tiltott témák, kulturális-etnikai különbözôségek hatása nemzetközi szerveződésekben.

11 Klasszikus értelemben vett ún. „kvázipiac”, ahol a felek egy nehezen beszerezhető árut (tudás) cserélnek ki az elvárt haszon érdekében. A haszon képviselhet nem anyagi ellenértéket is, mint például: hírnév, megbecsülés, reciprocitás (kölcsönösség).

12 Egységes definíciója nincs, mert a különböző szakterületek más-más dimenzióját emelik ki. A bizalom problémaköre bekerült a közgazdaságtudományi kutatások önálló (pl. játékelmélet, döntéselmélet, szervezetelmélet) és interdiszciplináris elemeket is tartalmazó megközelítéseibe (pl. magatartás-gazdaságtan, érzelem-gazdaságtan, identitás-gazdaságtan, gazdaságpszichológia).

13 Pl. tudásközvetítőként működő e-Learning vállalatok.

$14 \mathrm{Az}$ információvédelem fổ jellemzői: Titkosság és hozzáférhetôség: csak az arra jogosultak férhetnek hozzá az információkhoz, továbbá az információfeldolgozás helyességét biztosító sérthetetlenség.

15 Videokonferencia, e-mail, virtuális projekt stb.

16 Real-time knowledge sharing.

17 Ilyenek, mint: közös munkán dolgozó partnerszervezetek között, külső tanácsadók, szakértők alkalmazásánál belső szervezetfejlesztés során, külsổ képzési cég/előadó megbízásai.

18 Például az általános elvárásra - hogy mindenki a tudása legjavát adja a szervezetnek és segítse munkatársainak fejlődését felülrôl elrendelt formális tudásmegosztó fórumok.

19 Ma te segítesz nekem, holnap én neked. Vagy valaki más közülünk. „What goes around comes around...”

20 Például az ösztönzési rendszer kialakításával hatékonyabbá lehet tenni a tudásmegosztást. Vállalati intranetre lehet publikálni az új ismereteket, amelyért anyagi és nem anyagi jutalmakra átváltható kredit adható. Ilyen gyakorlat van: Acces Health, Knexa, Cap Gemini Accenture cégeknél. Bővebben: Swanstrom, E. (1999)

${ }^{21}$ Olyan tudáshordozó személy, akinek elsődleges célja saját tudásának megosztása a tudás átvevő aktorral és emellett a másik fél tudásbôvítésének támogatása (kapcsolatrendszer, tudásforrások, presztízs, közös munkák).

22 Olyan tudást átvenni szándékozó személy, aki saját tudásának bővítésére törekszik és ehhez formális és informális szervezeti tudásforrások, ezen belül személyi és tárgyi eszközök állnak rendelkezésére.

23 Akár formális szervezeti kereteken belül az aktorok viszonyának nevesítésével (mentor, gyakornok), akár informális csoportokban, illetve hálózatokban a tudásmegosztásbeli szerep spontán kialakulásával.

24 A tudástranszfert akadályozó gátak, amelyek lassítják, illetve meggátolják az információk áramlását.
25 Feltételei: rugalmasság, idő a tanulásra, nyitottság.

26 Ahol külön státus és jutalom jár a kizárólagos tudás birtoklásáért.

27 Csehországban és Lengyelországban szintén 10\% körüli.

28 Oroszország, Ukrajna, Belorusszia.

29 Eltérố történelmi ösvény.

30 Jellemző mentalitás: Megbízom a barátomban, de nem tudhatom, hogy vannak-e az ismerőseim, sőt rokonaim között besúgók. Eleve bizalmatlan vagyok az állami intézményekkel (rendôrség, tanács, adóhivatal) szemben.

31 Ezalatt a tranzakciókkal járó kockázat csökkentését is értem.

32 Polányi ezalatt a bizalomból kialakuló tekintélyt érti, és nem a kikényszerített, külső formális tekintélyt.

33 Érzelmi töltés, viszonyulás stb.

34 Alapja az egyértelmű és egymással összhangban lévố verbális (amit mondunk) és nem verbális (ahogyan tesszük) jelzésrendszer. Nem verbális kommunikáció: mimika, tekintet, hangszín, hangerô, intonáció, gesztusok, mozdulatok, távolságtartás stb.

35 Abszorpció képessége.

36 Adatbank, tudásmegosztó fórumok, tudásmegosztást elismerố jutalmazási rendszer, megfelelő technológiai bázis stb.

37 A nyereségek és költségek elemzése az aktor szemszögéből, mennyire éri meg az elvárttól eltérôen viselkedni, azaz felrúgni a játékszabályokat. Ezt befolyásolja az aktor hírneve. Rugalmassági hajlandósága, információközlésének nyíltsága, az aktorok közötti kapcsolat idôtartama és intenzitása, várható következményei stb.

38 Például személy esetén a bizalmatlanságot hívhatja elő az egyébként előzőleg jól működő viszonyban az, hogy a másik fél függelmi kapcsolatba kerül egy olyan féllel, akinek nem szeretném, ha tudomására jutna az adott információ, és nem szeretném kellemetlen helyzetbe hozni a másik félt sem azzal, hogy visszatartson egy olyan információt, amelyet kötelessége lenne a függelmi viszony miatt a harmadik féllel megosztani. Ide tartoznak véleményünk szerint az elhallgatott, illetve visszatartott információk is.

${ }^{39}$ Oka lehet: kölcsönös függőség, közös érdek, hálózati kapcsolat, reciprok altruizmus stb.

40 Néhány további lehetséges ok lehet még: büszkeség, önfejűség, időhiány, kedvezőtlen szervezeti környezet,...

41 Ilyenek, mint: jóindulat, kompetencia, kiszámíthatóság, tisztesség, lojalitás stb.

$42 \mathrm{Az}$ optimális bizalom nem egyenlő a feltétlen bizalommal Mindig egy adott kontextusra vonatkozik, mértéke lehet alacsony vagy magas, attól függően, hogy kire, mire és mikor alkalmazzuk. A kölcsönös függés határozza meg a bizalom optimális szintjét, azaz egyenes arányban változik a kettő. Erős kölcsönös függésnél magasabb kölcsönös bizalom az optimális (a teljesítmény várhatóan növekedni fog). Ha nem kölcsönös függés van, nagyobb a cserbenhagyás veszélye.

43 LPP: Legitimate Peripheral Participation.

44 Meghatározott formai keretekkel, célokkal, külső megerősítéssel (szervezeti erôforrásokat felhasználva) működổ csoport, team, projekt.

45 Spontán módon kialakuló közösség

46 Tudásközösségek, gyakorlati közösségek.

47 Tudásgazdaként megelôlegezze a bizalmat és keresse a közös pontokat, amelyekhez köthető az új tudás, tudásátvevőként merjen kérdezni, kísérletezni.

48 Itt magát az érzést hangsúlyozzuk, ebből a szempontból mellékes, hogy erre valós vagy vélt okok miatt kerül sor.

49 Amikor egy támogatott munkatárs tudatja másokkal informális csatornákon keresztül azt, hogy milyen segítőkész és nagy 
tudású a tudását megosztó kolléga, ez növelheti az önbecsülést. Ennek sorozatos elmaradása megrendítheti a saját magába, illetve a segítséget kérők szándékába vetett bizalmat.

50 Nyilvános elismerés anyagi és nem anyagi formái: magasabb fizetés, prémium, bónusz, jutalom, kitüntetés.

51 Előléptetés, biztos foglalkoztatás, kulcsemberként való besorolás.

52 A társadalmi tőke fogalmát az embercsoportok közös célokért való együttműködésének képességéhez köti. Az emberi tudás és szakértelem már önmagában is tôke. A bizalom határozza meg a társadalmi tőke lehetôségeinek kihasználását.

53 Amennyiben a politika és az állam a maga erejével e tudáshordozók érdekében hoz törvényeket, például: erôsíti a nukleáris családot, bizalmat teremt a közrend fenntartásával, javítja az oktatást.

54 A kutatás során alkalmazott egyéni kérdőívek válaszai alapján, kiegészítve az interjúk során elhangzottakkal. Bővebben: Garaj (2004).

55 Kapcsolati kockázatvállalásként is említi a szakirodalom.

56 A válaszolók egyéni választásai alapján történő összesítés, több lehetséges változat közül választhattak, ezért az egyes tényezôk összesítésének abszolút értéke nem 100\%. (pl. nem választott, csak egyet vagy kettôt, mindhármat).
57 Alapvető viszonyulás, általános érvényũ elvárás az emberi megbízhatóságról (lásd: hajlam).

58 Az egyes csoportokhoz tartozók több lehetséges változat közül választhattak, ezért az egyes tényezők összesítésének abszolút értéke nem $100 \%$.

59 Ugyanazt a jelenséget, történést, információt, tudásgazda személyét, tudástartalmat, metakommunikációt másként élünk meg attitűdünk, bizalomigényünk, hajlamaink, elổzetes tapasztalataink stb. alapján.

60 A vizsgált populáció $8 \%$-a.

61 A vizsgált populáció $35 \%$-a.

62 Mindazon készségek, kompetenciák és tulajdonságok, amelyek alkalmassá teszik az egyént arra, hogy adott területen valamilyen befolyással rendelkezzen.

63 A bizalom tárgya képes és törekszik az önérdekein felülemelkedni, és a benne megbízó személy érdekében cselekedni.

$64 \mathrm{Az}$ a bizonyosság, hogy a bizalom tárgya a benne megbízó számára elfogadható szabálykészletnek megfelelôen viselkedik.

65 Semlegesség, vagyis korrekt, objektív tényeken alapuló, becsületes törvényhozatal.

66 Minden bizalomfaktor alapja a velünk született általános érvényű elvárás (generalizált bizalom). Ez határozza meg azt, hogy az egyén mennyire fog megbízni másokban azelőtt, hogy konkrét információkkal rendelkezne róluk.

\section{Hibaigazítás}

2005. évi 11. számunkba két hiba is csúszott. Az „Integrált vállalat irányitási rendszerek a vállalati értékmaximalizálás szolgálatában" címü cikk szerzője helyesen Kopányi Tamás.

A „Gondolatok és kiutak a közgazdaságtanoktatásban” címü cikk tévesen szerepel lapunk boritóján, közlésére következö számunk egyikében kerül sor. 